\title{
The e-Learning Needs Analysis in Graduate Programs of Universitas Negeri Makassar
}

\author{
${ }^{1}$ Nurhikmah Hasyim, ${ }^{2}$ Abdul Haling \\ ${ }^{1}$ Department of Educational Technology, Universitas Negeri Makassar \\ Email: nurhikmah.h@unm.ac.id \\ ${ }^{2}$ Department of Educational Technology, Universitas Negeri Makassar \\ Email: abdulhaling62@gmail.com
}

(Received: November-2017; Reviewed: November-2017; Accepted: December-2017; Published: December-2017)

\begin{abstract}
This research aims to develop learning materials and tutorial videos e-learning for students of PPs UNM. Accurately, this research will produce learning materials, video tutorials, and scholarly articles. Product development refers to the ADDIE model (Analysis-Design-Develop-Implement-Evaluate) developed by Reiser and Mollenda in 1990. The research subject is graduate PPs UNM and the data gathering methods are documentation, interview, questionnaire, and tests, then analyzed by the descriptive qualitative method. In the first stage of research conducted analysis, i.e., identifying characteristics or profiles of prospective participants learn, identify gaps, and the identification of needs. The result shows, 1) characteristic of participants, i.e., in the range 25-35 years adult category, the respondent's gender dominated by women and respondents are dominated by kindergarten teacher/PAUD until lecturer, and they have a very high motivation to learn the program; 2) Some gap identify based on question form given to the respondents, i.e., they strongly agree with the application of e-learning-based lesson at school and University, but abilities and skills related to the program is still very limited; and 3) needed learning materials in the form of video tutorials that can help them to learn independently and master the lesson of e-learning based program.
\end{abstract}

Keywords: Needs Analysis; e-Learning.

\section{INTRODUCTION}

The development of information and communication technology have a significant influence on education. Speed is accompanied by demands for the needs of the potential donation can provide the education and training sector. The changes that happened not only impacted on the process but also on learning outcomes. Various innovations are being made to meet the demands of the times, ease of access to a wide range of learning resources are demanding learners and students for control of information and communication technologies are changing all the time. Potential of technology not only improves the efficiency and effectiveness of the learning process as well as the flexibility but also have an impact on the development of the material, shifting the role of teacher/trainer and the growing autonomy of learners. 
A variety of media and ICT-based learning model was developed, including computer-based learning by utilizing various software such as powerpoint, adobe flash, prezi, mindjet, and different other programs that allow learning can take place interactively and independent. One of the technology trends that are widely used today in learning program is elearning that it is assumed as the internet-based learning. While the models of learning are offered such as model-based learning e-learning which can be implemented through three ways, i.e., first, e-learning without classroom meetings so that all the learning process is carried out through the Internet without any face-to-face in a classroom. Second, e-learning by blending the regular class meetings are termed blended learning that is part of the learning process is carried out via the internet and partly implemented in the learning process in the classroom. Third, e-learning is used as an adjunct in the study typically serve as enrichment only.

Many of the benefits that can be gained by using the internet in learning, including ease of access, speed, cheaper cost, independence in learning, and can be active where and at any time due to the availability of facilities Internet everywhere. Another very obvious trend in the use of technology in learning is the availability and use of the internet broadly (Baer, 1998; Goffe \& Sosin, 2004; Hiemstra \& Poley, 2007; Oliver, 2005; Vogel \& Klassen, 2001). The results showed that more than $90 \%$ of the students have access to the internet on the campus of colleges and universities (Tutty \& Klein, 2008), and almost $79 \%$ of students agreed that using the Internet has increased the academic experience their colleges (the Pew Internet American Life \&, 2002).

There are three changes are necessary before realizing e-learning in full, namely: (1) must expand the basic understanding of what elearning it, (2) must add to the quality of the assessment into the e-learning product, (3) must genuinely instill evaluation in hard from the elearning initiative. (Revess, T.C., 2002). Online learning appears to be a need and is a great alternative to find challenges in the era of the development of information technology is so fast. However, when accessed online learning's environment correctly and widely efficiently expected not only in optimizing learning but also in reducing the cost of and increasing access and student satisfaction (Mohammed Eltahir Osma, 2005). Online learning is an increase in science and art that has the potential of giving the vastness in students to access the latest information anywhere and at any time, increase the liveliness and independence in learning and support communication with the experts.

E-learning-based lesson, on top of already implemented in schools and colleges in Indonesia, including UNM almost all faculties there are already making use of the internet in learning at both the level of S1, S2, or S3. It is supported by the internet facilities that are already prepared by the UNM with bandwidth $600 \mathrm{Mbps}$ enables to implement e-learningbased lesson for all courses.

E-learning becomes an obligation for students of UNM strata two PPs for controlled, both in the preparation of e-learning-based lesson that can be applied in school or teaching students to place on campus as well as used in interact with lecturer courses in Prodi respectively. To facilitate learning, e-learning, then developed learning materials and video tutorials that can help students learn independently when and where only. Based on the explanation above, researchers developed video tutorials and learning materials that can be used to study the UNM student PPs and steeped in e-learning. However, before developing in advance to do e-learning needs analysis at the UNM graduate programs.

Development of learning materials should be based on an analysis of the needs of the students. There are some reasons why the need for the development of learning materials, as mentioned by the Directorate of Coaching high school (2008:8-9) as follows, namely, the availability of materials according to curriculum demands, meaning that the learning materials developed must be in accordance with the curriculum, the characteristics of the target, says that the learning materials can be adjusted to the characteristics of students as the target, the characteristics include social environment, culture, geographical and user development stages, teaching materials should be able to answer or solve problems or difficulty in learning. Thus, the development of learning materials needs to pay attention to students characteristics and needs of students.

Learning materials developed in the form of video tutorials. The video is an 
advantageous medium to help the learning process, both for mass, individual learning, and group. According to Daryanto (2010:87), the video is a non-print material that is rich in information, and thoroughly as it can forward students directly. Also, the video adds a new dimension to learning, and this is because the characteristics of video technology that can present a motion picture in the accompanying voices, besides. The video program can give you unexpected experiences to students, and the video program can be combined with animation and speed settings to demonstrate changes from time to time. Various types of videos are used to assist in the process of learning one is the video tutorial. A video tutorial is a guide on how to explain something, either learning or training material (training) as well as the process of the operation of a system (hardware and software) that is packaged in the form of a video. In other words, the media video tutorial learning is a teaching tool or media which contain messages in pursuit of learning, and independent audiovisual basis without having to be accompanied by a teacher. Audiovisual media as video and has an element of motion would be able to attract the user's attention and motivation to study independently in the exercise of the activity of learning.

A video tutorial is a technology that can be used in learning. Technology is often seen as something unusual, open border, and it is crucial for the future of this learners now. But there are still many learners not sure how beneficial unites technology in daily routine, especially in a class composed of students with different skills and abilities. Incorporate educational technology into teaching (2006:4th Edition), by M.D. Roblyer, can serve as a guide for candidates and teachers practice to use appropriate technology with everyday situations (Cathy G.K., 2006).

Based on the description, this research aimed to develop teaching materials and elearning video tutorial for students PPs UNM. However, before developing the first phase of the analysis, firstly identify the characteristics or profiles of prospective learners, gap identification, and needs identification.

\section{METHODS}

Research is the research development that adapted the model of development of ADDIE (Analysis-Design-Develop-ImplementEvaluate) developed by Reiser and Mollenda in 1990. At the first stage of the analysis done of which is the analysis of the needs of e-learning on students in UNM PPs by identifying characteristics or profiles of prospective participants learn, identify gaps, and the identification of needs. Research subject graduate PPs UNM with techniques of data collection is the documentation, interview, the now and the then analyzed tests are qualitative, descriptive.

\section{RESULTS AND DISCUSSION}

\section{Results}

By the development steps followed, i.e., ADDIE model, then the first step is to do the analysis presented as follows. Data collected from 687 respondents who were taught craftingbased learning, e-learning and has given online question form to identify the characteristics of potential participants, the identification of gaps, needs identification and analysis the detailed tasks based on the needs.

Based on the questionnaire, data shows that dominantly respondents in 25-35 years namely $69 \%$, this indicates that the participants are at ages range which very productive to developing various forms of innovative learning , primarily related to information technology and communication. Based on questionnaire, data also shows that the repondents gender are dominant by women, equal $58.2 \%$.

Table 1. Age of respondent

Age of Respondents

\begin{tabular}{ccccc}
\hline$<25$ & Between & Between & Betwwn 36- & \multirow{2}{*}{ Total } \\
Years & $26-30$ & 31-35 Years & 40 Years & Years
\end{tabular}




\begin{tabular}{rrrrrr}
\hline \multicolumn{7}{c}{ Years } & & & & \\
\hline 63 & 302 & 107 & 64 & 151 & 687 \\
\hline $9 \%$ & $44 \%$ & $16 \%$ & $9 \%$ & $22 \%$ & $100 \%$ \\
\hline
\end{tabular}

Data based on question form also obtain information that $73.7 \%$ of respondents are educators, while others are the real student (no job) and employees of educational institutions.

Diagram 1. Teaching in Educational Units

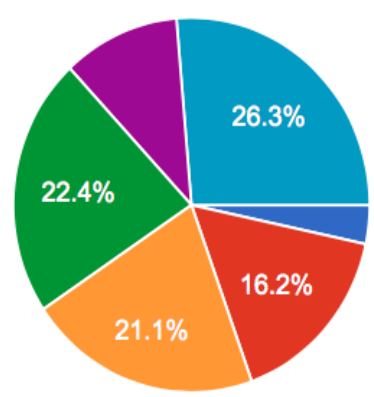

Next question form provided consisting of 10 items of the statement with a choice answers ranging from strongly agree, agree,
This result shows that they need introduction and development of preparation tutorial-based learning, e-learning, to make this learning can be developed and used in each school.

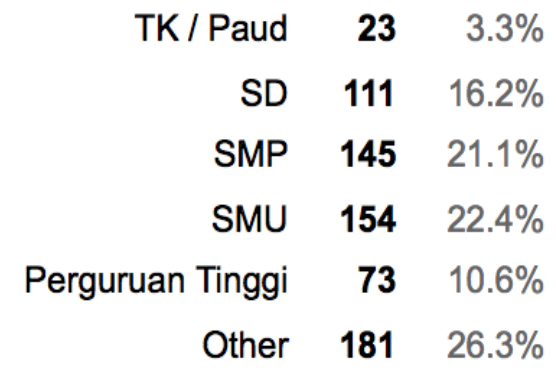

disagree, and strongly disagree regarding the development of tutorials and learning materials for students of UNM, PPs the following data now set out one by one.

Diagram 2. Very happy with the Internet-based learning/E-learning

\begin{tabular}{|rrrr|}
\hline Sangat Setuju & $\mathbf{4 1 6}$ & $60.6 \%$ \\
Setuju & $\mathbf{2 6 5}$ & $38.6 \%$ \\
Ragu & $\mathbf{6}$ & $0.9 \%$ \\
& Tidak Setuju & $\mathbf{0}$ & $0 \%$ \\
& Sangat Tidak Setuju & $\mathbf{0}$ & $0 \%$ \\
& & & \\
\hline
\end{tabular}

The above data shows as much as $99 \%$ strongly agree and agree with the statement was very pleased with the e-learning-based lesson. It shows the motivation and the desire of students to explore this program further. Neither in diagram 4 the respondent gives strongly agree and agree to response when teachers and professors to manage e-learning-based lesson while only one respondent who did not agree.

Diagram 3. I agree in a Learning-based e-learning Applied In Middle School. 


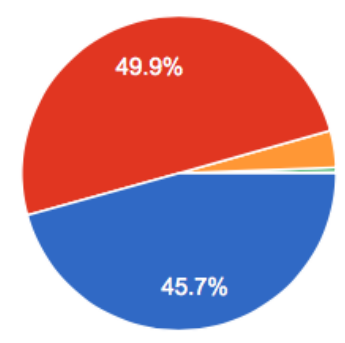

$\begin{array}{rrr}\text { Sangat Setuju } & \mathbf{3 1 4} & 45.7 \% \\ \text { Setuju } & \mathbf{3 4 3} & 49.9 \% \\ \text { Ragu } & \mathbf{2 6} & 3.8 \% \\ \text { Tidak Setuju } & \mathbf{3} & 0.4 \% \\ \text { Sangat Tidak Setuju } & \mathbf{1} & 0.1 \%\end{array}$

The responses of the respondents against the application of e-learning in high school showed $95.6 \%$ agree and strongly agree to implement.

Diagram 4. Teachers and professors should be able to Manage Learning-based e-Learning.
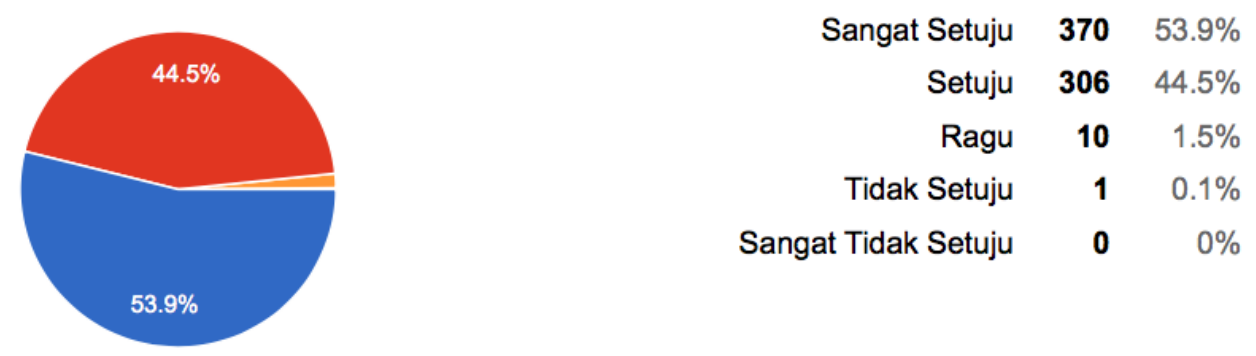

Diagram 5 shows that as much as $97.7 \%$ of the respondents agree and strongly agree in casebased learning e-learning applied in college.

Diagram 5. I agree in a Learning-based e-Learning Applied in College

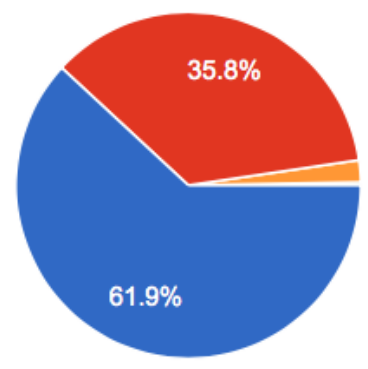

$\begin{array}{rrr}\text { Sangat Setuju } & \mathbf{4 2 5} & 61.9 \% \\ \text { Setuju } & \mathbf{2 4 6} & 35.8 \% \\ \text { Ragu } & \mathbf{1 4} & 2 \% \\ \text { Tidak Setuju } & \mathbf{2} & 0.3 \% \\ \text { Sangat Tidak Setuju } & \mathbf{0} & 0 \%\end{array}$

Diagram 6 and 7 indicates that respondents were more dominant agree and strongly agree that the menu and icon in the e-learning-based lesson, easy to understand, this is, of course, the young respondent's age contribute against the ease in understanding existing programs in e-learning.

Diagram 6. In the menu-based learning, e-Learning/Internet I Understand Easily 


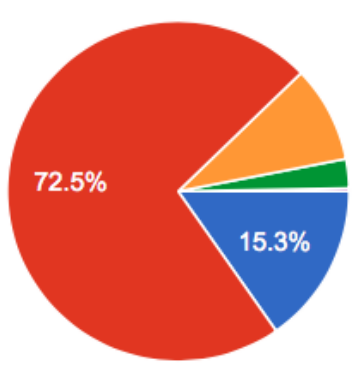

$\begin{array}{rrr}\text { Sangat Setuju } & \mathbf{1 0 5} & 15.3 \% \\ \text { Setuju } & \mathbf{4 9 8} & 72.5 \% \\ \text { Ragu } & \mathbf{6 3} & 9.2 \% \\ \text { Tidak Setuju } & \mathbf{1 9} & 2.8 \% \\ \text { Sangat Tidak Setuju } & \mathbf{2} & 0.3 \%\end{array}$

Diagram 7. Icon in the e-Learning-based lesson/Internet I Understand Easily

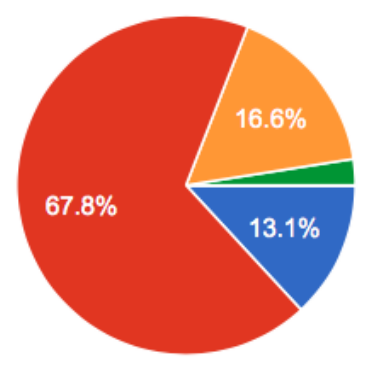

$\begin{array}{rrr}\text { Sangat Setuju } & \mathbf{9 0} & 13.1 \% \\ \text { Setuju } & \mathbf{4 6 6} & 67.8 \% \\ \text { Ragu } & \mathbf{1 1 4} & 16.6 \% \\ \text { Tidak Setuju } & \mathbf{1 7} & 2.5 \% \\ \text { Sangat Tidak Setuju } & \mathbf{0} & 0 \%\end{array}$

Diagram 8. e-learning/Internet-based lesson Made Me Motivate in learning

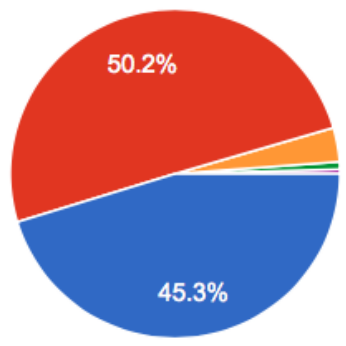

Diagram 8 shows that as many as $95.5 \%$ of the respondents can be motivated in learning once by implementing e-learning-based lesson. One of the students who has been taught drawing up a learning-based e-learning gives his opinion about e-learning, i.e., learning elearning is a breakthrough in the world of education to make the learners can learn independent e-learning also offers distance learning and can be accessed anywhere and anytime with the notes connected with the internet. In the process of learning e-learning, I

$\begin{array}{rrr}\text { Sangat Setuju } & \mathbf{3 1 1} & 45.3 \% \\ \text { Setuju } & \mathbf{3 4 5} & 50.2 \% \\ \text { Ragu } & \mathbf{2 3} & 3.3 \% \\ \text { Tidak Setuju } & \mathbf{5} & 0.7 \% \\ \text { Sangat Tidak Setuju } & \mathbf{3} & 0.4 \%\end{array}$

find it easier to understand because of the practice more than a theory. A lot of things that I got after learning e-learning of which I learned how to manage a course, I do know how to draw up a learning-based e-learning and the most memorable during the process of learning elearning is When I can make the writing goes. Possible for friends and seniors I make writing goes something most accessible and have no impression of anything on them, but for me, that's the thing that was memorable, results of an interview with Husriadi in July 2016. 
Diagram 9. I am confused utilizing e-Learning Program

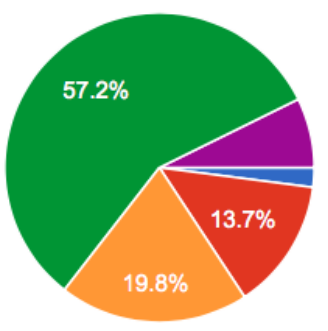

$\begin{array}{rrr}\text { Sangat Setuju } & \mathbf{1 4} & 2 \% \\ \text { Setuju } & \mathbf{9 4} & 13.7 \% \\ \text { Ragu } & \mathbf{1 3 6} & 19.8 \% \\ \text { Tidak Setuju } & \mathbf{3 9 3} & 57.2 \% \\ \text { Sangat Tidak Setuju } & \mathbf{5 0} & 7.3 \%\end{array}$

Diagram 9 shows, as much as $64.5 \%$ disagree when expressed mystified in utilizing the elearning program.

Diagram 10. All courses/Subjects should be accessible through the Internet

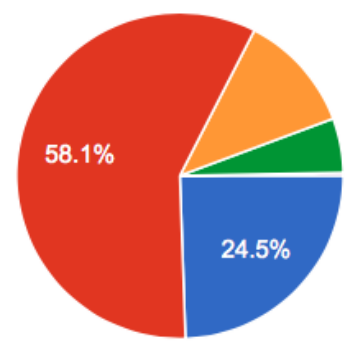

$\begin{array}{rrr}\text { Sangat Setuju } & \mathbf{1 6 8} & 24.5 \% \\ \text { Setuju } & \mathbf{3 9 9} & 58.1 \% \\ \text { Ragu } & \mathbf{8 1} & 11.8 \% \\ \text { Tidak Setuju } & \mathbf{3 7} & 5.4 \% \\ \text { Sangat Tidak Setuju } & \mathbf{2} & 0.3 \%\end{array}$

Diagram 11. Learners must be able to Access the Learning through the internet

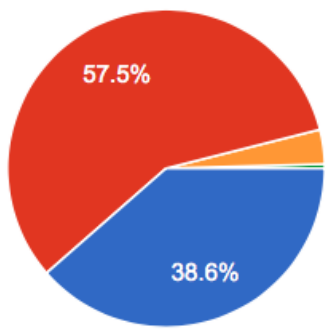

$\begin{array}{rrr}\text { Sangat Setuju } & \mathbf{2 6 5} & 38.6 \% \\ \text { Setuju } & \mathbf{3 9 5} & 57.5 \% \\ \text { Ragu } & \mathbf{2 4} & 3.5 \% \\ \text { Tidak Setuju } & \mathbf{3} & 0.4 \% \\ \text { Sangat Tidak Setuju } & \mathbf{0} & 0 \%\end{array}$

Charts 10 and 11 also shows that respondents agree and strongly agree when courses or subjects can be accessed through the internet, neither the learner shall have the ability to be able to access the learning.

\section{Discussion}

The respondent was in a very productive age in developing various forms of innovative learning, especially concerning information and communication technologies. According to Thomas Toth (2003) in Hamdani (2011:115) explains that e-learning is all that covers the utilization of computers in supporting improved quality of learning, including the use of mobile technologies, such as PDAs and MP3 players. 
Also the use of teaching materials and webbased hypermedia, multimedia CD-ROMs or websites, discussion forums, collaborative software, wikis, blogs, e-mail, computer-aided assessment, educational animations, simulations, games, software learning management, electronic voting system, and others. All these programs will be quickly known, understood, and operated by those who are still young and not technological literacy. Usually, people, who are an old fool with the most excellent technology with the reason they are old and already want to retire.

In addition to younger, dominant respondents working as educators ranging from kindergarten teacher/OLD until College. This condition indicates that the need for the developed video tutorials to help educators understand more profoundly and independentlybased learning e-learning which became the learning demands of the present and the future. Empy \& Hartono (2005:22) suggests that there are two main parts, namely E-learning Learning Management System content and e-learning or e-learning subject matter. Where LMS is a system that helps the Administration and serves as a platform for e-learning content. This thing indicates that the concept of utilizing information technology education by using elearning in the process of teaching and learning will be able to provide waivers or ease for continuity of learning.

The above data shows as much as $99 \%$ strongly agree and agree with the statement was very pleased with the e-learning-based lesson. It shows the motivation and the desire of students to explore this program further. The respondents also agree when teachers and professors to manage e-learning-based lesson. Provides online learning packages through the internet is one of the learning efforts, though without any learner who teaches. Miarso (2004:553-554) states that learners can perform learning activities without a learner must have teaching and learning activities, but in learning activities, students must have learned. The selection of the learningbased e-learning course depends on the ability of teachers and professors in the use of information technology in the conduct of its activities.

The responses of the respondents against the application of e-learning in high school showed $95.6 \%$ agree, and strongly agree to apply, the study conducted by Hagie and
Hughes (2005), the participation of learners in online learning in the classroom shows the success of the students relating to the subject matter and content mastery demonstrated that asynchronous online discussion introduced the self-improvement on the individual. While other advantages such as independent study for students, uninterrupted communication or communication with educators of learners could be anywhere and anytime, cost-effective, and learners can find plenty of sources study at a time.

Diagram 6 shows that as much as $96.7 \%$ of the respondents agree and strongly agree in case-based learning e-learning applied in college. Zerr (2007) found that one of the utilization of online media used in homework in calculus courses, shows an increase in learning achievement of students, positive attitude and excellent response against the model the granting of duty online. But this application should pay attention to several things including facilities and infrastructure are prepared so that this program can be run by expectations. Purbo (2002) requires three things that must be met in designing internet-based learning, that is "simple, personal, and quickly." Further, Purbo (2002) states that in internet-based learning need to be created as if learning of students conventionally, it into digital systems over the internet.

E-learning offers learning which is flexible in the sense that e-learning can be accessed anywhere and anytime as long as within reach of the internet. However, onlinebased learning (e-learning) need the motivation of high learning. The phenomenon happens now sometimes there are people who can motivate other people but it is difficult to motivate himself, and it was a problem. So, e-learning lesson should be designed such that, it can stir up one's motivation to want to learn.

Charts 10 and 11 also shows that respondents agree and strongly agree when courses or subjects can be accessed through the internet, neither students shall have the ability to be able to access the learning. Some opinions about the advantages of e-learning-based lesson as follows.

a. Thick idea Exploration; additional comments or conversation in a more in-depth discussion (Gupta et al., 2005). 
b. All arguments can be saved forever. This thing allows students to review or revisit the content, implementation time and from anywhere.

c. Online learning Environment was offering more freedom to express disapproval and to other questions (Wenger, 1998).

d. Students receive the benefits from learning community where they can build more vibrant discussions and have more time (Collison et al. 2000).

e. everyone can work at a time that is most convenient for them and in their environment by the conditions which are most conducive to their style of working.

f. Through the use of technology, all learning styles and needs/limitations can be met in an optimal learning environment so that all students can develop.

\section{CONCLUSION AND SUGGESTION}

1. The characteristics of the participants, i.e., the age of about 25-35 years adult category, dominant women and gender of respondents of the dominant power of education ranging from kindergarten teacher/OLD until College, and they have a very high motivation to learn that program.

2. Some gaps that are identified based on question form given to the respondents, i.e., they strongly agree with the application of elearning-based lesson at school and University, but abilities and skills related to the program is still insufficient.

3. Required materials in the form of video tutorials that can help them learn to study and master the program-based learning e-learning independently.

\section{Advice}

1. The development of e-learning-based lesson should pay attention to two essential things namely human resources and means of tools.
2. Students and prospective teachers should have competence in drawing up a learningbased e-learning.

3. Determining the policy should identify needs and analysis of problems in the application of learning-based e-learning.

4. Pay attention to the characteristics of the participants in the adult category, then the learning required in the selection of the learning model andragogy.

\section{REFERENCE}

Baer, W. S. (1998). Will the Internet Transform Higher Education? (ERIC Document Reproduction Service No. ED 434551).

Cher Ping Lim. (2005). Online Learning In Higher Education: Necessary And Sufficient Conditions. International Journal of Instructional Media. New York: Vol.32, Iss. 4; pg. 323, 9 pgs.

Collison, G., Tinker, R., Elbaum, B., \& Haavind, S. (2000). Facilitating Online Learning: Effective Strategies for Moderators. Madison: Atwood Publishing, LLC.

Daryanto, (2010). Media Pembelajaran (Peranannya Sangat Penting Dalam Mencapai Tujuan Pembelajaran). Yogyakarta: Gava Media

Eltahir Osman, Mohamed .(2005). Students' Reaction To Webct: Implications For Designing On-Line Learning Environments. International Journal of Instructional Media. New York, Vol.32, Iss. 4; pg. 353, 10 pgs.

Empy Effendi \& Hartono Zhuang. (2005). ELearning Konsep \& Aplikasi. Yogyakarta: Andi Yogyakarta.

Gupta, S., Eastman, J. K., \& Swift, C. O. (2005). Creating an Effective Online Learning Environment: A Shift in the Pedagogical Paradigma. Academy of Educational Leadership Journal, 9(3), 79-88.

Goffe, W. L., \& Sosin, K. (2005). Teaching With Technology: May you Live in Interesting Times. The Journal of Economic Education, 36(3), 278-291.

Hughes, M. \& Hagie C. (2005). The Positive and Challenging Aspects of Learning Online and in Traditional Face-to-Face Classrooms: A Student Perspective. 
Journal of Special Education Technology, Vol. 20, (8-52).

Hamdani. (2011). Strategi Belajar Mengajar. Bandung:Pustaka Setia.

Hiemstra, R. \& Poley, J. (2007). Lessons Pertinent for Teaching With Computers. Journal of Educational Strategies. Issues and Ideas, 80(3), 144-148.

Miarso, Y. H. (2004). Menyemai Benih Teknologi Pendidikan. Jakarta: Prenada Media.

Oliver, R. (2005). Ten More Years of Educational Technologies: How far have we travelled. Australian Educational Computing, 20(1), 1-8.

Pavlik, J. V. (1996). New Media Technology. Culture and Commercial Perspectives. Singapore: Allyn and Bacon.

Tutty, J. I., \& Klein, J. D. (2006). Effects of Collaboration Mode and Group Composition in Computermediated Instruction. International Convention of the Association of Educational Communications and Technology, Dallas, TX.

Vogel, D. \& Klassen, J. (2001). TechnologySupported Learning: Status, Issues and Trends. Journal of Computer Assisted Learning, 17, 104-114.

Wenger, E. (1999). Communities of Practice: Learning, Meaning, and Identity. Cambridge University Press. 